\title{
AN APPARATUS MAKING POSSIBLE RESTORATION OF SIMPLE FUNCTIONS OF THE TETRAPLEGIC HAND ${ }^{\star}$
}

\author{
By J. Kiwerski, M. D. and R. Pasniczek, Eng.D. \\ Rehabilitation Institute, Konstancin, Poland.
}

Summary. In the Rehabilitation Institute at Konstancin investigations and clinical tests have been carried out over the last ten years with a view to restoring the tetraplegic hand function by means of implanted stimulation of the peripheral nerves of the upper extremity. Lately, an apparatus for a tetraplegic has been constructed, based on patient controlled stimulation of the median and radial nerves. In this report the principle of the apparatus and also the initial clinical tests are discussed.

Investigations carried out so far have demonstrated that grasping function of the hand is compatible with the projected programme and that the induced function of the hand is useful for the patient.

Key words: Tetraplegia; Implanted stimulators; Orthopaedic apparatus for tetraplegics.

RECENTLY, a steady increase of severe injuries of the spine and spinal cord has been recorded in Poland. Despite simultaneous increase of intensive medical care in the acute post-traumatic period, and improvement of treatment methods, the number of patients with tetraplegic paralysis resulting from spinal cord injuries has increased (Kiwerski and Chrostowska, I980).

Often such injuries affect the spinal cord in the C6-- 7 segment, causing paralysis of the peripheral part of the extremity, i.e. hand with simultaneous preservation of function of the dynamic groups of the shoulder, as well as flexors of the elbow joint. Patients with injuries of this kind, deprived of the possibility of performing the simplest self-service functions, are completely dependent on their environment and require the care and help of the accompanying person.

In the Rehabilitation Institute at Konstancin investigations and clinical tests have been carried out over a period of Io years, aiming at restoration of the tetraplegic hand functions by means of implanted stimulation of peripheral nerves of the upper extremity (Pasniczek et al., I972; Kiwerski, I973; Kiwerski and Pasniczek, I973; Kiwerski et al., I979).

Lately our efforts brought about the construction (in co-operation with Warsaw Technical University), of an apparatus based on programmed control by the patients, using alternating stimulation of the median and radial nerves (Morecki et al., I978; Morecki et al., I980).

The apparatus for programmed control of the paralysed hand to promote grasping function is composed of three basic parts:

I. A set of implanted stimulators.

2. Programming and controlling mechanism.

3. An orthosis placed on the extremity.

^ Paper read at the I.M.S.P. Meeting in Athens, Greece, October 1982. 
The orthosis serves as a hand and also immobilises the wrist and the thumb in relation to the forearm.

The set of implanted stimulators serves for excitation of the radial and median nerves, thus being instrumental in obtaining extension and flexion of the fingers.

The programming and controlling mechanism secures a suitable sequence for switching on the different phases of the forced grasping function.

Moreover, the apparatus is equipped with two transducers, the 'position' and the 'touch' ones, working in the feedback systems regulating angular velocity of the finger flexion motion, as also initial magnitude of the grasping force.

The initial phase begins with radial nerve stimulation, causing finger extension and hand opening with a view to grasping the object. After directing the hand to the object to be grasped, the patient switches on median nerve stimulation, causing gentle flexion of fingers up to the moment of grasping the object and, next, of closing his fingers on it with determined initial force magnitude. Initial grasping force is fixed at the level of $2 \mathrm{~N} \pm 20$ per cent, being sufficient for lifting light objects. When the grasping force is of a magnitude insufficient for raising the object the patient has the opportunity of increasing this force by means of three degrees change of stimulation level. The next phase involves stimulation of the radial nerve, facilitating removal of the hand from the object. To excite muscles performing this task stimulators implanted under the skin of the paralysed extremity are used. The electrodes are placed near the median and radial nerves, selecting such a location as to achieve painless and effective stimulation. Suitable programming of each pair of stimulators creates conditions

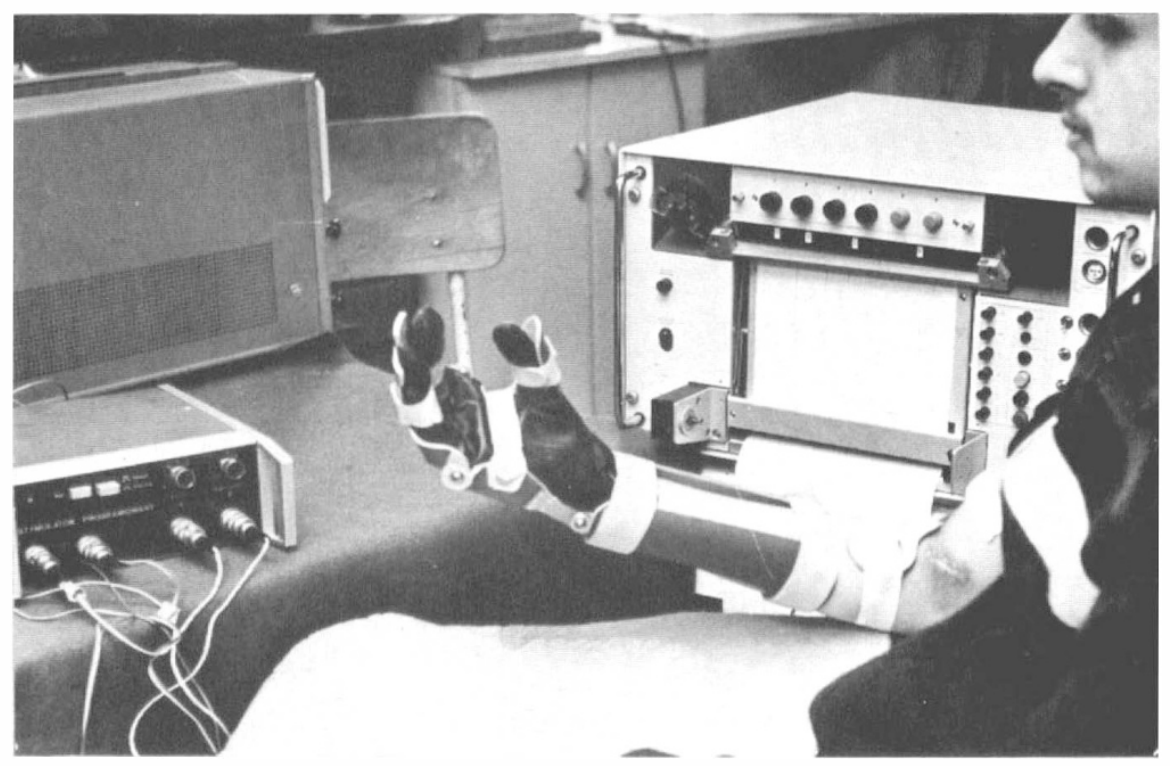

FIG. I

Apparatus in use. 
necessary for obtaining a functionally useful movement of the paralysed hand.

This apparatus was used in three patients with complete injury of the spinal cord at the C6 level as a result of spinal fracture. At present, we are carrying out clinical investigations on its general usefulness for tetraplegics.

Figure I presents the apparatus and its clinical application.

During investigations we learnt the necessity of using an external orthosis on the paralysed extremity. This serves for functional hand forming, secures stabilisation of the wrist joint and the opposite thumb positioning. Lack of this orthosis makes impossible the functional use of the extremity, since (during median nerve stimulation), unfavourable palmar hand flexion accompanies the finger flexion and the thumb opposition. The external orthosis should be well fitted to the patient's hand and be light in order to avoid limitation of the kinetic possibilities of the paralysed extremity.

Investigations carried out until now, have demonstrated that grasping function of the hand as a result of stimulation of the paralysed muscle groups, is compatible with the assumed programme, and that the induced function of the hand is useful for the patient. After the object has been grasped by him the active muscles of the shoulder and groups of the elbow flexors allow him to raise or displace this object. Control of the apparatus makes no difficulties for the patient, is simple and unfailing.

\section{RÉSUMÉ}

A l'Institute de Réhabilitation à Konstancin on a entrepris des recherches et des épreuves cliniques pendant les dix dernières années qui avaient pour but de restaurer le fonctionnement de la main tetraplégique au moyen d'une stimulation implantée des nerfs periphéraux de l'extrémité supérieure. Récemment, on a construit un appareil pour un tetraplégique, basé sur la stimulation, contrôlée par le souffrant, des nerfs médians et radiaux. Dans ce rapport on discute du principe de l'appareil et des épreuves cliniques initiales.

Les recherches effectuées jusqu'ici ont démontré que la fonction de préhension de la main est compatible avec le programme projeté et que la fonction induite de la main est utile au souffrant.

\section{ZUSAMMENFASSUNG}

In der Wiederherstellungsanstalt in Konstancin sind Untersuchungen und klinische Prüfungen während der letzten zehn Jahre ausgeführt werden, und zwar mit der Absicht, die Funktion der tetraplegischen Hand mittels einer eingepflanzten Stimulation der peripheralen Nerven des oberen Gliedes wiederherzustellen. Neulich hat man einen Apparat für einen Tetraplegischen gebaut, der auf der von dem Pazient kontrollierten Stimulation von Nervus medianus und Nervus radialis basiert ist. In diesem Bericht diskutiert man den Prinzip des Apparates, wie auch die angfänglichen klinischen Prüfungen.

Die bisjetzt ausgeführten Untersuchungen haben gezeigt, dass die Greiffunktion der Hand vereinbar mit dem entworfenen Program ist, und dass die induzierte Funktion der Hand nutzvoll dem Pazient ist.

\section{REFERENCES}

KIWERSKI, J. (I973). The effects of electrical stimulation on paralysed muscles in quadriplegics. Pol. Tyg. Lekarski, 28, 158.

KIWERSKI, J. \& PAŚNICZEK, R. (I973). Early results of application of implanted stimulators in paralysis of upper extremities following spinal injury. Neurol. Neurochir. Polska, 7, 8 II. 
Kiwerski, J., Weiss, M. \& PAŚniczek, R. (I979). Electrostimulation of the median nerve in tetraplegics by means of implanted stimulators. F. of Rehabilitation Research, 2, 4I.

KIWERSKI, J. \& CHROSTOWSKA, T. (I980). Comparison of results of treatment of patients with cervical spine injuries in successive six-years periods. Chir. N. Ruchu i Ortop. Pol., 45, I09.

Morecki, A., Kiwerski, J., Paśniczek, R., Borowski, H. \& Gasztold, H. (1978). New conception of the hybrid system of supporting of the grasping movements. Advances in External Control of Human Extremities. Yugoslav Committee for Electronics and Automation. Belgrade, p. I47.

Morecki, A., Weiss, M., Kiwerski, J. \& Paśniczek, R. (I980). A new method for forcing lost grasping functions of extremities by use of an orthotic manipulator combined with implanted stimulator of nerves. International Conference on Medical Device and Sport Equipment. The American Soc. of Mechanical Engineers. San Francisco, Calif., p. 89.

PAŚNICZEK, R., KIWERSKI, J., BorOWSKI, H. \& WIRSKI, J. (I972). Some problems of implant stimulation applied to grasp motion. The Fourth International Symposium on External Control of Human Extremities. Dubrovnik, p. 584.

PaśniczeK, R., Kiwerski, J. \& Bialokoz, F. (I979). Implanted stimulating electrodes for the stimulation of tissue in a living organism. Probl. Techn. Med., I0, I85. 